Danylova, H. (1997). Metodychni sluzhby Ukrainy: problemy upravlinnia, profesiina pidhotovka [Methodical services of Ukraine: management problems, professional training]: navch.-metod. posib. Kyiv: IZMN. 224 s. [in Ukrainian].

Orban-Lembryk, L. (2010). Psykholohiia profesiinoi komunikatsii [Psychology of professional communication]: navch. posib. Chernivtsi: Knyhy - XXI. 528 s. [in Ukrainian].

Bondarchuk, O. (2008). Sotsialno-psykholohichni osnovy osobystisnoho rozvytku vykhovateliv u profesiinii diialnosti [Socio-psychological foundations of personal development of educators in professional activities]: monohrafiia. Kyiv: Naukovyi svit. 318 s. [in Ukrainian].

Butenko, T. (2009). Obgruntuvannia pedahohichnoi tekhnolohii formuvannia komunikatyvnoi kompetentnosti vykhovateliv [Substantiation of the pedagogical technolo- gy of the formation of the communicative competence of educators]. Pedahohika formuvannia tvorchoi osobystosti $u$ vyshchii $i$ zahalnoosvitnii shkolakh: zb. nauk. prats Klasychnoho pryvatnoho universytetu. № 3. S. 94-98. [in Ukrainian].

Kulish, O. (2006). Formuvannia osnov profesiinoho spilkuvannia u maibutnikh vykhovateliv [Formation of the foundations of professional communication among future educators]: avtoref. dys... kand. ped. nauk: 13.00.04. Luhansk. 20 s. [in Ukrainian].

Syndrom «profesiinoho vyhorannia» ta profesiina kariera pratsivnykiv osvitnikh orhanizatsii [The syndrome of «professional burnout» and the professional career of employees of educational organizations]: navch. posib. (2004). Kyiv: Milenium. 264 s. [in Ukrainian].

Дата надходження до редакиії: 25.08.2021 p.
УДК 371.2

DOI: 10.37026/2520-6427-2021-108-4-62-68

\section{Тетяна КОВБАСЮК,}

кандидат педагогічних наук, завідувач кафедри педагогіки, психологї та корекційної освіти Рівненського обласного інституту післядипломної педагогічної освіти, м. Рівне, Украӥна ORCID: 0000-0003-4551-3494 e-mail:kovbasyuktl@ukr.net

\title{
ПСИХОЛОГО-ПЕДАГОГІЧНІ ОСОБЛИВОСТІ МОТИВАЦЇ̈ ПЕДАГОГІВ ДО ПРОФЕСІЙНОЇ ДІЯЛЬНОСТІ
}

\begin{abstract}
Анотація. У статті здійснено аналіз психолого-педагогічних особливостей мотиваиії педагогів до професійної діяльності, досліджено ієрархічну структуру мотиваційної сфери, визначено основні мотиви діяльності вчителя. Проаналізовано фактори, шо впливають на формування професійної мотивації, визначено умови успішної професійної самореалізації. Для проведення емпіричного дослідження використано такі методики: тест «Мотивація професійноі діяльності» (методика К. Замфір у модифікаиії A. Peана), тест «Діагностика рівня професійної спрямованості» (Т. Дубовииької), методика «Задоволеність педагога обраною професією» (у модифікачиї А. Реана). Виявлено, що в респондентів, які нещодавно розпочали свою професійну діяльність, домінують мотиви досягнення сочіального престижу і поваги оточуючих та задоволення від самого прочесу і результатів праиі. Встановлено, щзо в учителів, стаж педагогічноі діяльності яких складає 6-15 років, найбільш актуалізованими є мотиви кар'єрного зростання та матеріального заохочення. Виявлено, щяо в осіб зі значним
\end{abstract}

стажем педагогічної діяльності домінують такі мотиви, як-от: можливість більше самореалізуватися саме в иій діяльності, грошова винагорода, бажання кар'єрного зростання, задоволення від самого процесу і результатів праці. Досліджено рівень професійної спрямованості педагогів, доведено, щзо з досвідом він поступово зростає від пасивного до креативного, однак в учителів, які працюють за спеціальністю більше 16 років, рівень креативності дещь знижується. Виявлено, щьо більшості педагогів притаманний середній рівень задоволеності професійною діяльністю, однак спостерігається ї̈ зростання відповідно до стажу роботи. Визначено, що формування та збереження позитивної внутрішньої мотивачї до професійної діяльності є одним із факторів, що сприяють підвищенню ефективності педагогічної взаємодії та створюють сприятливі умови для самореалізачії вчителя у професійній діяльності.

Ключові слова: мотив, мотивація, мотиваиійна сфера, педагогічна діяльність, професійна самореалізаиія. 
Tetyana KOVBASYUK,

Candidate of Pedagogical Sciences,

Head of the Department of Pedagogy,

Psychology and Correctional Education,

Rivne Regional Institute

of Postgraduate Pedagogical Education,

Rivne, Ukraine

ORCID: 0000-0003-4551-3494

e-mail:kovbasyuktl@ukr.net

\section{PSYCHOLOGICAL AND PEDAGOGICAL PECULIARITIES OF TEACHERS MOTIVATION ON PROFESSIONAL ACTIVITY}

\begin{abstract}
The article deals with the psychological and pedagogical features of teachers' motivation for professional activity. It hasd been investigated the hierarchical structure of the motivational sphere, identifies the main motives of the teacher. The it has been analyzed factors influencing on the formation of professional motivation. It has been determined conditions of successful professional self-realization.
\end{abstract}

The following methods were used to conduct the empirical study: test "Motivation of professional activity» (method Zamfir K. in the modification of Rean A.), test "Diagnosis of the level of professional orientation» (Dubovytska T.), method «Satisfaction of the teacher with the chosen profession» (modification Reana A.).

It was found that the respondents who have recently started their professional activity are dominated by the motives of achieving social prestige and respect for others and satisfaction with the process and results of work. It has been established that teachers whose experience in teaching is 6-15 years, the most relevant are the motives for career growth and earnings. It was found that people with significant experience in teaching are dominated by such motives as: the possibility of fuller self-realization in this activity, money, desire for career growth, satisfaction with the process and the results of work.

After studying the level of professional orientation of teachers, it was found that it increases with experience from passive to creative, but teachers who have been working in the specialty for more than 16 years, the level of creativity is somewhat reduced. It was found that most of the teachers have an average level of satisfaction with professional activities, but there is an increase in accordance with experience. It has been proved that the formation and maintenance of positive internal motivation for professional activity is one of the main factors that increase the effectiveness of pedagogical interaction and create favorable conditions for self-realization of teachers in the professional sphere.

Key words: motive, motivation, motivational sphere, pedagogical activity, professional self-realization.

Постановка проблеми. Дослідження особливостей мотивації педагогів до професійної діяльності залишається надзвичайно актуальним питанням, оскільки розуміння чинників, що спонукають особистість до вибору професії вчителя, зумовлюють надання переваги певному стилю викладання, дозволяють підтримувати необхідний рівень активності у процесі здійснення професійних функцій, сприяють знаходженню механізмів та технологій підвищення ефективності професійної діяльності педагога. Це видається особливо важливим у контексті впровадження у систему шкільної освіти інновацій та інтеграції української освіти у європейський простір. Відповідно глибше розуміння ціннісно-мотиваційних аспектів професійної діяльності педагога сприятиме оптимізації взаємодії у системі «вчитель - учень» та перешкоджатиме професійному вигоранню педагогів.

Аналіз наукових досліджень і публікацій. Особливості мотивації професійної діяльності педагогів є об'єктом досліджень у сучасній науці. Так, О. Білостоцька (2016), вивчаючи підходи до розуміння мотивації, виокремила такі з них: структурний - мотивація розглядається як сукупність мотивів; динамічний - мотивація як процес чи механізм; системний - мотивація як поєднання особистісних та ситуативних параметрів.

Важко не погодитись із позицією О. Браславської, яка акцентує увагу на тому, що мотиваційну сферу не варто розглядати відособлено від інших елементів структури особистості, оскільки спостерігається її тісний зв'язок із пізнавальною, емоційною та вольовою сферами (Браславська, Озерова, 2020).

Дослідниця наголошує на ієрархічній структурі мотивації професійної діяльності педагога, що містить такі компоненти, як: власне мотиви, потреби, інтереси, прагнення, цілі, установки, ідеали, що реалізуються у контексті зовнішньої та внутрішньої мотивації. Внутрішня мотивація виникає на основі інтересу, що передбачає цінність не результату, а процесу діяльності. Водночас зовнішня мотивація актуалізується тоді, коли причина діяльності лежить поза іiї процесом. Таким чином, саме інтерес до педагогічної діяльності є однією з важливих спонук, які забезпечують успішне оволодіння нею та подальшу самореалізацію особистості в обраній сфері. Вже на етапі навчання в закладі вищої освіти формується система професійних мотивів, що характеризується індивідуальним змістом та основується на характері особистості, стилі ії міжособистісної взаємодії, психофізіологічних особливостях тощо. У зв'язку з цим важливою умовою успішної самореалізації педагога є якісний перехід навчальної мотивації у професійну (Браславська, Озерова, 2020).

Професійна мотивація, на думку О. Сагач, $є$ системою чітко усвідомлених спонукань, що мають внутрішню природу, знаходяться в певній ієрархії та визначають особистісний зміст діяльності педагога. Змістовна 
наповненість професійної мотивації, на думку науковця, визначається сукупністю потреб, мотивів та цілей, що зумовлюють напрям особистісної активності педагога, наповненість його діяльності, емоційний полюс ставлення до неї, а в результаті і до самого себе, оскільки задоволеність професійною самореалізацією вплітається в структуру «Я-концепції» особистості, визначаючи поряд із іншими чинниками специфіку самосприйняття (Сагач, 2019).

А. Волянюк (2021) виокремлює такі групи мотивів діяльності вчителя: матеріальні, які спрямовані на задоволення базових потреб; соціальні, що передбачають задоволення потреби в спілкуванні, приналежності до групи, визнанні та повазі; самостверджувальні, які забезпечують самореалізацію особистості як професіонала.

Дещо іншої думки дотримується О. Сагач, яка стверджує, що мотивація професійної діяльності педагога заснована на таких мотивах: матеріальних, навчальних інтересів, науково-пізнавальних, наслідування, суспільної значущості професії, іiі перспективності, прагнення бути корисним, впливу на вибір сфери діяльності значущих людей (Сагач, 2019).

Чимало дослідників стверджують, що провідні мотиви майбутньої професійної діяльності визначаються ще на етапі навчання особистості у закладі вищої освіти. Так, на думку А. Волянюк, підвищенню мотивації до професійної діяльності майбутніх педагогів сприяють такі прийоми, як: підтримання постійного зворотного зв'язку; використання інтерактивних форм навчання; визначення ресурсів та цілей кожної особистості; усвідомлення рівня власної мотивації; коригування навчального матеріалу відповідно до інтересів суб'єктів освітньої діяльності; підтримка тісного взаємозв'язку теорії і практики; створення умов, сприятливих для підвищення самооцінки (Волянюк, 2021).

О. Браславська, досліджуючи чинники, що зумовлюють вибір професії педагога, виокремила такі 3 них: інтерес до педагогічної діяльності, що не згасає з часом; актуалізовані соціальні мотиви, зокрема мотив соціального визнання; можливість творчої самореалізації у професії; переважання внутрішніх мотивів; стійке прагнення до самореалізації в освітній галузі (Браславська, Озерова, 2020).

Специфіка мотивації навчальної діяльності в закладі вищої освіти визначає наявність чи відсутність прагнення до професійного зростання педагога вже у процесі виконання ним професійних функцій, тобто вже на етапі навчання у закладі вищої освіти в особистості формується ставлення до майбутньої професії, відбувається усвідомлення власної ролі в контексті суб'єкт-суб' єктних стосунків у процесі взаємодії з учнями, включення в структуру «Я-образу» соціальної ролі педагога. Зважаючи на це, така підструктура «Я-концепції», як «Я-ідеальне» повинна включати уявлення про себе як педагога, наприклад, якими якостями особистість хотіла б володіти, виконуючи професійну діяльність (Сагач, 2019).

На думку І. Дубровіної, у структурі мотивації до професійної діяльності значну роль відіграє спрямованість на самоосвітню діяльність, в основу якої покладено потребу у самовдосконаленні. Важливою умовою іiі розвитку є сукупність зовнішніх факторів: підтримка колег і адміністрації; ставлення до вчителя учнів та їхніх батьків; матеріальне заохочення; наявність об'єктивних факторів, сприятливих для самореалізації тощо. Підвищенню мотивації до самоосвітньої діяльності сприяє актуалізація потреби у самовдосконаленні, розвиток здатності до самовизначення, набуття нових психолого-педагогічних знань, формування духовного світогляду (Дубровіна, 2017).

Успішна професійна самореалізація педагога пов'язана зі сформованістю в нього мотивації досягнення, що включає в себе такі компоненти: відповідні потреби, активна особистісна позиція, очікування успіху, позитивне соціальне підкріплення, сприятливий емоційний стан, чітке усвідомлення бажаного результату. Відповідно важливими $є$ такі характеристики мотивації: повнота іiї структури, збалансованість мотивів, концентрація на позитивному досвіді (Савиченко, Шуневич, 2018).

За даними Т. Куценко (2016), мотивація професійної діяльності вчителів значною мірою залежить від якостей учнів, з якими вони працюють. Так, учителі більше мотивовані на роботу з дисциплінованими учнями, в яких розвинені організаційні здібності та які мають високу успішність. Важливу роль відіграє також бажання учня співпрацювати з учителем, його орієнтація на отримання знань.

На думку О. Бондарчук (2017), одним із факторів, що впливають на мотивацію до професійної діяльності, $€$ психологічна безпека освітнього середовища, що передбачає гуманістичну орієнтованість, попередження проявів психологічного насильства, референтність для особистості мікросоціуму, в якому вона перебуває, підтримка кожним членом групи позитивного соціально-психологічного клімату. Сукупність цих умов сприяє створенню середовища, сприятливого для особистісного зростання як самого педагога, так і інших суб'єктів освітнього процесу.

Дослідниця стверджує, що показниками суб'єктивного благополуччя $є$ : самоприйняття, зокрема й позитивне сприйняття свого минулого; відчуття постійного самовдосконалення та професійного зростання; усвідомлення цінності свого життя, передусім професійного; здатність підтримувати позивну взаємодію 3 іншими; здатність керувати власним життям, йти до намічених цілей; ефективне самовизначення (Бондарчук, 2017).

За даними М. Бирки, до мотивів продовження педагогічної діяльності варто віднести: прагнення впливати на становлення підростаючого покоління; реалізувати свій потенціал у контексті роботи вчителя; працювати в культурному середовищі та в умовах цікавого професійного спілкування; сприяти вихованню дітей; сприяти соціальному розвитку молоді, інтелектуальних здібностей учнів та ін. (Бирка, 2014).

Цінними є результати досліджень О. Браславської, яка виділила такі шляхи підтримання мотивації до педагогічної діяльності: чітке усвідомлення специфіки професії, розкриття суспільної значущості; володіння новітніми технологіями викладання; підтримання активної позиції; усвідомлення можливості особистісного та професійного зростання. Формуванню професійної 
мотивації сприяє актуалізоване прагнення до самовдосконалення, тенденція розвивати аналітичні вміння, сформована здатність до рефлексії, вміння передбачати наслідки педагогічних впливів (Браславська, Озерова, 2020).

Незважаючи на значну кількість досліджень 3 означеної проблеми, в сучасній науці залишаються недостатньо вивченими особливості мотивації до професійної діяльності, зумовлені стажем педагогічної роботи.

Мета статті - дослідити динаміку мотивації до професійної діяльності у педагогів із різним періодом трудової діяльності.

Виклад основного матеріалу дослідження. Емпіричне дослідження особливостей мотивації педагогів до професійної діяльності проводилося нами на базі Рівненського обласного інституту післядипломної педагогічної освіти у 2021 році. Ним було охоплено 60 учителів із різним педагогічним стажем: від одного до п'яти років, 6-15 років, більше 16 років. Кожна група складалася 320 осіб. Для проведення психодіагностики використовувалися такі методики: тест «Мотивація професійної діяльності (методика К. Замфір у модифікації А. Реана), тест «Діагностика рівня професійної спрямованості» (Т. Дубовицької), методика «Задоволеність педагога обраною професією» (у модифікації А. Реана). У процесі обробки результатів використано метод математичної статистики, а також $\varphi^{*}$-критерій кутового перетворення Фішера.

Результати, отримані за допомогою тесту «Мотивація професійної діяльності» (методика К. Замфір у модифікації А. Реана), представлені в таблиці 1.

Таблиця 1

Мотиви професійної діяльності педагогів (у \%)

\begin{tabular}{|c|c|c|c|}
\hline $\begin{array}{ll}\text { Мотив } & \text { Стаж } \\
\end{array}$ & 1-5 років & 6-15 років & $\begin{array}{l}\text { Більше } \\
16 \text { років }\end{array}$ \\
\hline Грошова винагорода & 15 & 20 & 30 \\
\hline Бажання кар’єрного зростання & 10 & 25 & 20 \\
\hline Прагнення уникнути критики з боку керівництва або колег & 15 & 10 & 5 \\
\hline Прагнення уникнути можливого покарання & 10 & 5 & 5 \\
\hline Потреба у досягненні соціального престижу і поваги оточуючих & 25 & 15 & 10 \\
\hline Задоволення від самого процесу і результатів праці & 20 & 15 & 20 \\
\hline Можливість більше самореалізуватися саме в цій діяльності & 5 & 10 & 30 \\
\hline
\end{tabular}

Отримані результати дають підстави стверджувати, що в респондентів, стаж роботи яких становить 1-5 років, домінує такий мотив професійної діяльності, як потреба в досягненні соціального престижу і поваги оточуючих (25\%). Педагоги, які тільки розпочинають свою професійну діяльність, прагнуть реалізувати в її контексті вищих соціальних потреб, що вказує на конструктивну спрямованість мотиваційного процесу загалом. Молоді вчителі намагаються продемонструвати на практиці знання, здобуті у закладах вищої освіти, віднайти своє місце в соціумі, бути активними членами суспільства, виконуючи соціально визнану діяльність.

Достатньо вираженим у цій групі респондентів $\epsilon$ такий мотив, як задоволення від самого процесу і результатів праці (20\%). Це вказує на те, що молоді вчителі здатні до вибору конструктивних форм провадження педагогічної діяльності та побудови комунікації з учнями, що сприяє продуктивному обміну психічною енергією між суб'єктами впливу та перешкоджає розвитку синдрому професійного вигорання.

Менш вираженими є мотиви заробітку (15\%), прагнення уникнути критики з боку керівництва або колег $(15 \%)$, прагнення уникнути можливого покарання (10\%), бажання кар'єрного зростання (10\%).

Мотив заробітку не є домінуючим у вибірці у зв'язку з тим, що більшість респондентів усе ще проживають із батьками та ще не стикнулася з необхідністю самостійно себе забезпечувати, що зменшує рівень актуалізованості фінансового мотиву.
Частині респондентів притаманна негативна мотивація, в основу якої покладено страх критики та покарання з боку керівництва. Актуалізації таких мотивів сприяє те, що молоді вчителі ще не мають достатнього досвіду педагогічної діяльності, не впевнені у власних силах, бояться зробити помилку та викликати осуд колег.

Недостатня вираженість мотиву кар'єрного зростання пов'язана з тим, що молоді вчителі лише набувають досвіду професійної діяльності, пробують свої сили у цій сфері та поки що не будують планів щодо кар'єрного зростання.

Невираженим у цій групі респондентів є мотив більше самореалізуватися саме в цій сфері діяльності (5\%). Це пояснюється тим, що означену частину вибірки становлять особи, які нещодавно закінчили заклад вищої освіти і розпочали свою професійну діяльність, зокрема частина 3 них має сумніви в тому, чи правильно вони обрали професію, чи зможуть самореалізуватися саме в цій сфері.

Аналіз результатів, отриманих у респондентів, стаж роботи яких становить 6-15 років, вказує на домінування в них мотиву кар'єрного зростання (25\%). У цей період педагоги відчувають, що вже адаптувалися до вимог професії, здобули необхідний досвід, що спонукає їх шукати можливості просування службовою драбиною.

Достатньо вираженим у цій групі респондентів $\epsilon$ мотив заробітку (20\%), що відображає ставлення до професії передусім як до джерела прибутку, а вже 
потім як до сфери самореалізації, що узгоджується 3 пірамідою потреб А. Маслоу, відповідно до якої незадоволеність потреб нижчого порядку перешкоджає задоволенню вищих соціальних потреб.

Дещо менш вираженими є мотиви досягнення соціального престижу і поваги оточуючих (15\%), задоволення від самого процесу і результатів праці (15\%), прагнення уникнути критики з боку керівництва або колег $(10 \%)$, можливість повнішої самореалізації саме в цій діяльності (10\%).

Невираженим $є$ мотив уникнення можливого покарання (5\%), що може бути пов'язано з наявністю певного досвіду взаємодії з керівництвом та впевненістю у власній кваліфікації.

У респондентів, стаж педагогічної діяльності яких становить більше ніж 16 років, домінуючим $є$ мотив грошової винагороди (30\%), оскільки більшість із цієї групи вчителів мали можливість за цей час здобути певну кваліфікаційну категорію, що забезпечило їм підвищення заробітної плати та дозволило сприймати професійну діяльність як стабільне джерело прибутку.

Одним із домінуючих у зв'язку з цим є мотив більшої самореалізації саме в цій діяльності (30\%). Така тенденція пояснюється тим, що досвідчені вчителі вже осягнули особливості професії, вона є для них сферою самореалізації. Демонструючи педагогічну майстерність та отримуючи задоволення від результатів праці, вони відчувають власну цінність як професіонала, прагнуть і далі розвиватися у цій галузі.

Достатньо вираженими є мотиви кар'єрного зростання (20\%) та задоволення від самого процесу і результатів праці (20\%). Педагоги готові до виконання незвичних соціальних ролей у межах нової посади, не бояться брати на себе відповідальність, що з цим пов'язана, прагнуть спробувати свої сили, виконуючи нові для них професійні обов'язки, що розширює їхні можливості самореалізації як педагогів. Крім того, вчителі із цієї підгрупи відчувають задоволення від проробленої роботи, взаємодії з учнями, високо оцінюють результати своєї діяльності, що сприяє збереженню позитивної мотивації.

Менш вираженим $є$ мотив досягнення соціального престижу і поваги оточуючих (10\%), що пов'язано 3 домінуванням внутрішньої мотивації та достатньої впевненості особистості в собі як у професіоналі, що зменшує актуальність потреби в тому, щоб отримувати зовнішнє підтвердження успішності своєї діяльності.

Невираженими є мотиви уникнення критики 3 боку керівництва або колег та можливого покарання (5\%). Це зумовлено досвідченістю цієї підгрупи респондентів, впевненістю у своїх силах та власному професіоналізмі.

Для визначення того, чи є статистично значущими відмінності мотиваційної сфери в різних підгрупах респондентів, нами використовувався $\varphi *$-критерій кутового перетворення Фішера. Зокрема, було з'ясовано, що в респондентів зі стажем більше 16 років домінує мотив заробітку $\left(\varphi^{*}=2,91\right.$, при $\left.\varphi^{*}{ }_{\text {кр }}=1,64, \mathrm{p}<0,05\right)$ та мотив повнішої самореалізації в педагогічній діяльності $\left(\varphi^{*}=2,74\right.$, при $\left.\varphi^{*}{ }_{\text {кр }}=1,64, p<0,05\right)$, тоді як в учителів зі стажем 1-5 років переважає мотив уникнення критики 3 боку керівництва або колег ( $\varphi^{*}=1,95$, при $\varphi^{*}{ }_{\text {кр }}=1,64$, $\mathrm{p}<0,05)$ та потреба в досягненні соціального престижу i поваги оточуючих $\left(\varphi^{*}=1,82\right.$, при $\left.\varphi^{*}{ }_{\text {кр }}=1,64, \mathrm{p}<0,05\right)$.

Для доповнення отриманих даних ми використали тест «Діагностика рівня професійної спрямованості» Т. Дубовицької, результати якого представлено в таблийі 2.

Таблиия 2

Рівень професійної спрямованості педагогів (у \%)

\begin{tabular}{|l|c|c|c|}
\hline \multicolumn{1}{|c|}{ Стаж } & $\mathbf{1 - 5}$ років & $\mathbf{6 - 1 5}$ років & Більше 16 років \\
\hline Критичний & 0 & 0 & 0 \\
\hline Пасивний & 10 & 5 & 0 \\
\hline Базовий & 55 & 35 & 30 \\
\hline Оптимальний & 25 & 35 & 50 \\
\hline Креативний & 10 & 25 & 20 \\
\hline
\end{tabular}

Порівняння показників респондентів із різним стажем педагогічної діяльності вказує на те, що в усіх підгрупах відсутні особи з критичним рівнем професійної спрямованості, який проявляється у відсутності уявлень про професію, знань про свої професійні обов'язки, навиків роботи.

Зі збільшенням стажу спостерігається зниження кількості вчителів, яким притаманний пасивний рівень професійної спрямованості, що полягає в амбівалентному ставленні до професії, відсутності чіткого образу себе як педагога, нездатності підібрати власний стиль педагогічної діяльності, який би узгоджувався з індивідуальними особливостями особистості та відповідав актуальним вимогам діяльності.

Кількість осіб, яким притаманний базовий рівень професійної спрямованості, зменшується зі збільшенням стажу педагогічної діяльності, що супроводжується переходом особистості на якісно новий (оптимальний чи креативний) рівень. Загалом базовий рівень характеризується наявністю в особистості уявлень про себе як педагога, усвідомленням своїх професійних функцій, вимог професії, труднощів, що можуть виникати на кожному етапі діяльності.

Кількість учителів, яким властивий оптимальний рівень професійної спрямованості, збільшується з набуттям відповідного стажу. Цей рівень визначається чітким розумінням вимог професії, усвідомленням своїх якостей як педагога, здатністю обирати різні форми впливу на учнів у процесі освітньої діяльності, володінням широким арсеналом педагогічних прийомів.

Дослідження динаміки креативного рівня професійної спрямованості вказує на неоднорідність 
його прояву. Так, найнижчі показники спостерігаються в осіб зі стажем роботи 1-5 років, далі відбувається зростання в респондентів зі стажем 6-15 років, а от в учителів, стаж роботи яких перевищує 16 років, відзначається спад. Така тенденція пояснюється тим, що частина педагогів зі значним досвідом роботи використовує у своїй діяльності вже знайомі й апробовані технології та методи роботи, що робить їхню діяльність менш креативною, аніж на попередніх етапах професійного становлення, коли домінувало прагнення до впровадження різноманітних інновацій.

У процесі роботи нами також використовувалася методика «Задоволеність педагога обраною професією» (у модифікації А. Реана). Отримані результати представлено в таблиизі 3.

Таблиия 3

Задоволеність педагогів обраною професією (у \%)

\begin{tabular}{|l|c|c|c|}
\hline \multicolumn{1}{|c|}{ Стаж } & $\mathbf{1 - 5}$ років & $\mathbf{6 - 1 5}$ років & $\begin{array}{c}\text { Більше } \\
\mathbf{1 6} \text { років }\end{array}$ \\
\hline Високий & 25 & 35 & 40 \\
\hline Середній & 60 & 55 & 55 \\
\hline Низький & 15 & 10 & 5 \\
\hline
\end{tabular}

Помітно, що зі збільшенням стажу педагогічної діяльності зростає і задоволеність професією $\left(\varphi^{*}=2,73\right.$, при $\left.\varphi^{*}=1,64, \mathrm{p}<0,05\right)$, що пов'язано з розвитком професійної ідентичності, кращим усвідомленням вимог професії, становленням особистості як професіонала, засвоєнням продуктивних форм роботи з учнями, кращим оволодінням педагогічними технологіями тощо.

Задоволеність професією безпосередньо пов'язана 3 тим, наскільки в процесі роботи задовольняються потреби особистості на різних рівнях їі функціонування (біологічному, соціальному, духовному), чи не відчуває вона фрустрацію / депривацію, пов'язану з професійною діяльності, наскільки задоволена їі потреба в розвитку та самореалізації.

Висновки. Мотивація професійної діяльності передбачає сукупність мотивів та потреб, що знаходять своє вираження і задоволення в процесі праці. Переважання внутрішніх мотивів над зовнішніми забезпечує чітку структуру мотиваційного процесу на професійну діяльність, створює умови реалізації всіх актуалізованих потреб особистості. Позитивна мотивація сприяє отриманню задоволення від професійної діяльності, створює умови для успішної самореалізації в обраній сфері. Натомість негативна мотивація супроводжується відчуттям внутрішньої напруги, страху та тривоги, що деструктивно впливає на формування професійної ідентичності.

Емпіричне дослідження динаміки професійної мотивації залежно від стажу педагогічної діяльності дозволило виявити, що в респондентів, які нещодавно розпочали свою професійну діяльність, домінують мотиви досягнення соціального престижу і поваги оточуючих, а також задоволення від самого процесу i результатів праці. Водночас мотив повнішої самореалізації саме у цій діяльності практично не представлений у цій підгрупі респондентів.

В учителів, стаж педагогічної діяльності яких складає 6-15 років, найбільш актуалізованими є мотиви кар'єрного зростання та грошової винагороди. Натомість прагнення уникнути можливого покарання в цій підгрупі невиражене.

В осіб зі значним стажем педагогічної діяльності домінуючими є такі мотиви: можливість більшої самореалізації саме в цій діяльності, грошова винагорода, бажання кар'єрного зростання, задоволення від самого процесу і результатів праці, а от мотив уникнути можливого покарання в мотиваційній сфері цієї підгрупи практично відсутній.

Дослідження рівня професійної спрямованості педагогів дозволило встановити, що він зростає 3 досвідом, від пасивного до креативного, однак в учителів, які працюють за спеціальністю понад 16 років, рівень креативності дещо знижується.

Більшості педагогів притаманний середній рівень задоволеності професійною діяльністю, однак її зростання спостерігається зі збільшенням стажу роботи.

На основі виявлених закономірностей можемо констатувати, що формування та збереження позитивної внутрішньої мотивації до професійної діяльності $\epsilon$ одним із факторів, що сприяють підвищенню ефективності педагогічної взаємодії та створюють сприятливі умови для самореалізації вчителя у професійній діяльності.

Перспективи подалыших досліджень. Зважаючи на те, що спектр досліджень особливостей мотивації педагогів до професійної діяльності є достатньо широким, подальшого вивчення потребує те, який вплив чинять на вчителів оволодіння новими практиками педагогічної діяльності та освіта впродовж життя.

\section{СПИСОК ВИКОРИСТАНОЇ ЛІТЕРАТУРИ}

Білостоцька, О. В. (2016). Структура мотиваційної сфери особистості майбутнього вчителя музичного мистецтва. Молодий вчений. № 12.1 (40). C. 387-391.

Браславська, О., Озерова, Л. (2020). Теоретичні основи формування професійної мотивації майбутнього вчителя в умовах фахової підготовки. Проблеми підготовки сучасного вчителя. № 2 (22). С. 21-30.

Сагач, О. (2019). Мотивація як складова професійного розвитку майбутнього вчителя. Педагогічна освіта: теорія і практика. Вип. 27. С. 105-110.

Волянюк, А. С. (2021). Розвиток сталої мотивації у майбутніх вчителів початкової школи в умовах змішаного навчання. Open educational e-environment of modern University. № 10. C. 56-66.

Дубровіна, I. В. (2017). Педагогічне забезпечення формування позитивної мотивації вчителів на 
самоосвітню діяльність. Науковий часопис НПУ імені М. П. Драгоманова. Серія 16 «Творча особистість учителя: проблеми теорії і практики». Вип. 29. С. 160-165.

Савиченко, О. М., Шуневич, О. М. (2018). Ресурси позитивної психотерапії для розвитку мотивації вчителів у післядипломній педагогічній освіті. Молодий вчений. № 4 (56). С. 528-532.

Куценко, Т. В. (2016). Формування мотивації професійної самореалізації вчителів у системі методичної роботи. Наукові записки кафедри педагогіки. Харківський національний педагогічний університет імені Г. С. Сковороди. Вип. 39. С. 124-128.

Бондарчук, O. I. (2017). Психологічна безпека освітнього середовища закладів загальної середньої освіти та її вплив на мотивацію інноваційної діяльності вчителів. Вісник післядипломної освіти. Серія «Соиіальні та поведінкові науки». Вип. 4-5. С. 17-27.

Бирка, М. Ф. (2014). Концептуальні засади підвищення мотивації вчителів природничо-математичних дисциплін до професійного розвитку. Педагогічна освіта: теорія і практика. Психологія. Педагогіка. № 21. C. 69-73.

\section{REFERENCES}

Bilostotska, O. V. Struktura motyvatsiinoi sfery osobystosti maibutnoho vchytelia muzychnoho mystetstva [The structure of the motivational sphere of the personality of the future teacher of music]. Molodyi vchenyi. 2016. № 12.1. (40). S. 387-391. [in Ukrainian].

Braslavska, O., Ozerova, L. Teoretychni osnovy formuvannia profesiinoi motyvatsii maibutnoho vchytelia $\mathrm{v}$ umovakh fakhovoi pidhotovky [Theoretical bases of professional formation of motivation future teacher in the conditions of professional training]. Problemy pidhotovky suchasnoho vchytelia. 2020. № 2 (22). S. 21-30. [in Ukrainian].

Sahach, O. Motyvatsiia yak skladova profesiinoho rozvytku maibutnoho vchytelia [Motivation as a component of professional development of the future teacher]. Pedahohichna osvita: teoriia i praktyka. 2019. Vyp. 27. S. 105-110. [in Ukrainian].
Volianiuk, A. S. Rozvytok staloi motyvatsii u maibutnikh vchyteliv pochatkovoi shkoly v umovakh zmishanoho navchannia [Development of sustainable motivation in future primary school teachers in blended learning]. Open educational e-environment of modern University. 2021. № 10. S. 56-66. [in Ukrainian].

Dubrovina, I. V. Pedahohichne zabezpechennia formuvannia pozytyvnoi motyvatsii vchyteliv na samoosvitniu diialnist [Pedagogical support for the formation of positive motivation of teachers for self-educational activities]. Naukovyi chasopys NPU imeni M. P. Drahomanova. Seriia 16 "Tvorcha osobystist uchytelia: problemy teorii i praktyky». 2017. Vyp. 29. S. 160-165. [in Ukrainian].

Savychenko, O. M., Shunevych, O. M. Resursy pozytyvnoi psykhoterapii dlia rozvytku motyvatsii vchyteliv $\mathrm{u}$ pisliadyplomnii pedahohichnii osviti [Resources of positive psychotherapy for the development of teacher motivation in postgraduate pedagogical education]. Molodyi vchenyi. 2018. № 4 (56) S. 528-532. [in Ukrainian].

Kutsenko, T. V. Formuvannia motyvatsii profesiinoi samorealizatsii vchyteliv u systemi metodychnoi roboty [Formation of motivation of professional self-realization teachers in the system of methodical work]. Naukovi zapysky kafedry pedahohiky. Kharkivskyi natsionalnyi pedahohichnyi universytet imeni H. S. Skovorody. 2016. Vyp. 39. S. 124-128. [in Ukrainian].

Bondarchuk, O. I. Psykholohichna bezpeka osvitnoho seredovyshcha zakladiv zahalnoi serednoi osvity ta yii vplyv na motyvatsiiu innovatsiinoi diialnosti vchyteliv [Psychological safety of the educational environment of general secondary education and its impact on the motivation of innovative activities of teachers]. Visnyk pisliadyplomnoi osvity. Seriia «Sotsialni ta povedinkovi nauky». 2017. Vyp. 4-5. S. 17-27. [in Ukrainian].

Byrka, M. F. Kontseptualni zasady pidvyshchennia motyvatsii vchyteliv pryrodnycho-matematychnykh dystsyplin do profesiinoho rozvytku [Conceptual bases of teachers motivation increasing of natural and mathematical disciplines to professional development]. Pedahohichna osvita: teoriia i praktyka. Psykholohiia. Pedahohika. 2014. № 21. S. 69-73. [in Ukrainian].

Дата надходження до редакиіï: 11.10.2021 p. 